\title{
Assessment of commonly used Hospital Disinfectants on Bacteria isolated from the Operating Theatre
}

\author{
Obi C. ${ }^{1 *}$, Muhammad U. K. ${ }^{1}$, Manga S. B. ${ }^{1}$, Atata R. F. ${ }^{2}$ and Hauwa T. ${ }^{3}$ \\ 1Department of Microbiology, Faculty of Sciences, Usmanu Danfodiyo University Sokoto, Nigeria. \\ 2Department of Pharmaceutics and Pharmaceutical Microbiology, Faculty of Pharmaceutical Sciences, Usmanu \\ Danfodiyo University, Sokoto, Nigeria. \\ ${ }^{3}$ Department of Science Laboratory Technology, School of Science and Technology, Abubakar Tatari Ali Polytechnic, \\ Bauchi, Nigeria. \\ ${ }^{*}$ Corresponding author. E-mail: obichidiebere@gmail.com. Tel: +2348065942714.
}

Copyright @ 2016 Obi et al. This article remains permanently open access under the terms of the Creative Commons Attribution License 4.0, which permits unrestricted use, distribution, and reproduction in any medium, provided the original work is properly cited.

Received 25th May, 2016; Accepted 23rd July, 2016

\begin{abstract}
Assessment of commonly used hospital disinfectants on bacteria isolated from the operating theatre of Usmanu Danfodiyo University Teaching Hospital Sokoto was evaluated. Bacterial species were isolated by settling plate method, using Nutrient and MacConkey agar as the isolating medium. The isolates were fully characterized by standard methods. Isolated bacteria includes; Staphylococcus aureus, Staphylococcus epidermidis, Bacillus megaterium, Bacillus cereus, Streptococcus $s p$ and Bacillus subtilis. The in house disinfectants (Povidone iodine and Izal) used in the operating theatres was obtained and evaluated using Agar ditch diffusion method. Povidone iodine obtained from the operating theatre showed no zones of inhibition in all the isolates tested, Izal solution obtained from the theatres showed appreciable zones of inhibition. Povidone iodine purchased from a pharmacy store in town however produced zones of inhibitions ranging from $7.75 \mathrm{~mm}$ to $18.00 \mathrm{~mm}$. Killing rate for the most resistant isolates showed that $B$. megaterium, $S$. aureus and $B$. cereus required 25 to 30 minutes of exposure time for $8 \%$ Izal dilution to bring about the death of all resistant isolates. It was concluded that disinfection remain one of the most effective ways of reducing nosocomial pathogens in hospital environment as demonstrated in the results of this research work. However, from time to time potency of the in house used disinfectant must be evaluated in order to keep pace with degradation of disinfectant which normally occurs with time.
\end{abstract}

Key words: Efficacy of disinfectant, nocosomial pathogens, hospital disinfectants, operating theatre.

\section{INTRODUCTION}

Microbial contaminations of the operating theatre and other specialized units have continuously increased the prevalence of nosocomial infection in our hospital environment (Allerberger et al., 2002). With direct effect on the high morbidity and mortality rate among patients admitted for post-operative surgery as well as patients in intensive care units with multi-drug resistant strains like methicillin-resistant Staphylococcus aureus (MRSA) have shown difficulty in infection control (Zerr et al., 2005). In our hospital setting especially in the operating theatre, reduction of microbial contamination depends primarily on improved cleaning and proper disinfection of the hospital environment, especially high risk areas as these measures are crucial in stemming down dissemination of these microbial infection (Frindkin et al., 1996). Infections by these microorganisms are often difficult to treat because of its virulence, intrinsic and acquired antibiotic resistance, which subsequently limit the choice of effective antimicrobial agents (Zavascki et al., 2005).

However, since the identification of microorganisms as the causative agents of infectious diseases, various methods have been devised in order to reduce the population and prevalence of these organisms. These methods include chemotherapy, immunization, sterilization and disinfection (Kim et al., 2007). Subsequently, decontamination, disinfection and sterilization became basic components of any infection control program (Rutala and Weber, 2001). A wide variety 
of clinical agents are used as disinfectants in healthcare settings, and these include, glutaraldehyde, sodium hypochlorite, phenolics, quartenary ammonium compounds (QAC), and chlorhexidine. They are used for a variety of medical, pharmaceutical, industrial and other purposes. They are generally low-level disinfectants showing activity against Gram-positive and Gramnegative bacteria (MacBain et al., 2004). However, S. aureus and $S$. epidermidis has been reported to particularly demonstrate resistance to biocides (Higgins et al., 2001).

Furthermore, antimicrobial activity of disinfectants have been influenced by their formulation effects, level of organic load, synergy, temperature, dilution rate and tests methods (Russel and Russel, 2005). Gram-negative bacilli have been tested for susceptibility to disinfectants with various disagreeing results (Rutala et al., 2007; Saurina et al., 1997). The widespread use of antiseptic and disinfectant products has also prompted some specialists to speculate on the development of microbial resistance to them and the subsequent cross-resistance to antibiotics (McDonnel and Russel, 2001).

Therefore, the selection, use and control of effectiveness of disinfectants have been emphasized, since environmental surfaces, medical and surgical instruments can serve as vehicles to infectious agents in susceptible hosts associated with the hospital setting (Rutala et al., 2007). In view of the importance of disinfection in the prevention of nosocomial infections, and some reports which claimed that antimicrobial activity of disinfectants are concentration-dependent, the aim of this study is to assess the commonly used hospital disinfectants on bacteria isolated from the operating theatre of Usmanu Danfodiyo University Teaching Hospital, Sokoto, Nigeria. The study will also verify whether the in house-concentration of $5 \%$ of povidone iodine and $8 \%$ izal employed by the hospital is effective.

\section{MATERIALS AND METHODS}

\section{Sampling area}

The study was conducted at Usmanu Danfodiyo University Teaching Hospital (UDUTH) Sokoto, between February and May, 2014. UDUTH is a tertiary hospital and a major referral centre in the North West geo-political zone of Nigeria. It also serves other neighboring countries like Niger and Benin Republics. The study sites were the operating theatres. The criteria for selecting the study sites were based on the fact that these sites are expected to be sterile.

\section{Sample collection}

Samples were collected from all the six operating theatres and its surrounding units. The main operating rooms include; Theatre 1 ( $T_{1}$, Orthopaedics surgery), Theatre 2 ( $T_{2}$, Ear, nose and throat and neurosurgery), Theatre $3\left(T_{3}\right.$, Cardiothoracic surgery, neuro surgery, plastic surgery and maxillofacial), Theatre 4 ( $T_{4}$, Ophthalmic surgery), Theatre 5 ( $T_{5}$, Obstetrics and gynaecology and Emergency) and Theatre 6 ( $T_{6}$, Obstetrics and gynaecology) and other surrounding units includes; theatre seminar room (TSR), theatre sterile room (TStR), theatre pharmacy room (TPR), theatre corridor $1\left(T_{C_{1}}\right)$, theatre corridor $2\left(T_{2}\right)$, theatre reception room (TReR), theatre instrument room (TIR), theatre recovery room (TRR), and theatre toilets (Tt). These designated sites were all sampled and a total of seventy-six samples (76) were collected in all the areas mentioned.

\section{Sampling procedure}

The plates of Nutrient and MacConkey agar were exposed in all the areas mentioned above, for a period of $30 \mathrm{~min}$ (MacCullouch et al., 2002). The plates were then taken to microbiology laboratory and incubated at $37^{\circ} \mathrm{C}$ for $24 \mathrm{hr}$. After $24 \mathrm{hr}$ of incubation all the plates were observed for growth, the colonies were counted using electronic colony counter and recorded. Pure culture of all the colonies observed in each plate were prepared in nutrient agar slants and stored in refrigerator at $7^{\circ} \mathrm{C}$ for subsequent use.

\section{Identification procedure}

All the isolated bacteria species were gram stained and allowed to air dry thoroughly before it was examined under a microscope using oil immersion objective lens (X100) and observations were recorded as results. The gram stained bacteria was then viewed under oil immersion lens (X100) microscopy, with the view of identifying the morphological characteristics of each organism. Isolates were further subjected to biochemical test with a view of identifying the various identity of each isolate. The biochemical test includes; catalase test, coagulase test, indole test, voges-proskauer test, sugar fermentation test, motility test, starch hydrolysis test, egg yolk reaction test, arabinose test, manitol fermentation test (Barrow and Felthem 1993).

\section{Collection of commonly used disinfectants from the operating theatre}

The commonly used in house disinfectants at UDUTH operating theatres were obtained from the hospital management. These disinfectants include Povidone iodine and Izal solution. The concentrations of in house 
Table 1. The isolated bacterial pathogens and its frequency of occurrence.

\begin{tabular}{lcc}
\hline Organism & Frequency & Percentage (\%) \\
\hline B. cereus & 63 & 28.1 \\
B. megaterium & 44 & 19.6 \\
S. epidermidis & 40 & 17.9 \\
S. aureus & 36 & 16.1 \\
B. subtilis & 21 & 9.4 \\
Streptococcus sp & 20 & 8.9 \\
Total & $\mathbf{2 2 4}$ & $\mathbf{1 0 0}$ \\
\hline
\end{tabular}

used disinfectants used in the operating theatre are $5 \%$ for povidone iodine and $8 \%$ for izal.

\section{Determination of susceptibility of isolates to the disinfectant}

Effects of different concentrations of the disinfectants were measured on all isolated bacteria by preparing different concentrations of disinfectant. The following concentrations used in the operating theatres were prepared; for povidone iodine $2 \%, 3 \%, 4 \%, 5 \%$ and for izal $2 \%, 4 \%, 6 \%, 8 \%$. All isolated and identified bacterial species were standardized to $10^{6} \mathrm{cfu} / \mathrm{ml}$ (NCCLS, 1999). Agar ditch diffusion method was used to test the effectiveness of each disinfectant (Onaolapo, 1997). Plates containing Mueller Hinton agar were inoculated with standardized inoculums of the isolates as described by Onalopo (1997). Sterile cork borer of $8 \mathrm{~mm}$ were used and holes were created and the bottom partly covered with molten agar to prevent the disinfectant solution from draining away. Using sterile $1 \mathrm{ml}$ syringe, $0.1 \mathrm{ml}$ of the desired concentration of each disinfectant was added into each hole created, allowed to diffuse for $1 \mathrm{hr}$ and thereafter incubated at $37^{\circ} \mathrm{C}$ for $24 \mathrm{hr}$. After $24 \mathrm{hr}$, the zones of inhibition formed were measured and recorded using a millimeter ruler $(\mathrm{mm})$.

\section{Purchase of povidone iodine from a pharmacy store in town}

As a result of the failure of povidone iodine obtained from the operating theatre, a new povidone iodine was purchased from a pharmacy store in town, from the same manufacturer as of the one provided in the theatre. The same concentration was used as the one in the operating theatre; the purchased povidone iodine was used against all isolated bacteria. This was done to compare the activity of povidone iodine kept in the operating theatre and the povidone iodine purchased from a pharmacy store in town, to find out the reason for the failure of povidone iodine obtained from the operating theatre (Taiwo et al., 2002).

\section{Determination of the killing rate of resistant bacteria isolates resulting from disinfectant's activity}

Killing rate was determined for $S$. aureus, B. megaterium and $B$. cereus being the resistant isolates found in this work using Kelsey and Maurer (2001) method. $1 \mathrm{ml}$ of $10^{6}$ $\mathrm{cfu} / \mathrm{ml}$ of the test isolates was mixed with $9 \mathrm{ml}$ of different concentrations of each disinfectant solution. The sterile syringe was used and $0.1 \mathrm{ml}$ from the mixture was taken and plated on Mueller-Hinton agar at an interval of 0,5 , $10,15,20,25$ and $30 \mathrm{~min}$. The plates were then incubated at $37^{\circ} \mathrm{C}$ for $24 \mathrm{hr}$. Surviving bacteria were counted, and logarithms of the number of survivors were taken and plotted against time.

\section{RESULTS}

The frequency and percentage of occurrence of each bacterium, isolated is presented in Table 1. B. cereus accounted for $28.1 \% \quad(n=63)$, which has the highest percentage of occurrence, it was closely followed by $B$. megaterium with $19.6 \%(n=44)$, S. epidermidis accounted for $17.9 \%(n=40), S$. aureus accounted for $16.1 \%,(n=36)$, B. subtilis accounted for $9.4 \%(n=21)$ and Streptococcus sp accounted for $8.9 \%$ of occurrence $(n=20)$.

Table 2 showed the distribution of bacterial pathogens isolated from the operating theatres and other surrounding units. $B$. cereus dominated in all the units sampled with $28.1 \%$ occurrence $(n=63)$, in the operating theatre and its surrounding units.

Table 3 showed the comparative sensitivity of isolated bacteria to different concentrations of UDUTH and Pharmacy povidone iodine. None of the tested isolates was sensitive to any of the concentrations of povidone iodine collected from the operating theatres (Table 3 ). Similar results were obtained from a repeated test carried out on the same isolates using the same concentrations of povidone iodine. Hence no zones of inhibition were observed from all the isolates. But from the povidone iodine purchased from a pharmacy store in town, all the isolates showed appreciable zones of inhibition using the same concentrations used in the hospital. $S$. aureus was most sensitive with $18.00 \mathrm{~mm}$ zone of inhibition at a 
Table 2. Distribution of bacterial pathogens isolated from the operating theatres and their surrounding units.

\begin{tabular}{|c|c|c|c|c|c|c|c|}
\hline Location & Site & B. cereus & S. aureus & B. megaterium & S. epidermidis & B. subtilis & Streptococcus sp \\
\hline \multirow{9}{*}{ Theatres } & $\mathrm{OT}_{1}$ & - & - & 7 & 4 & - & 1 \\
\hline & $\mathrm{OT}_{2}$ & 4 & 3 & - & - & - & 1 \\
\hline & $\mathrm{OT}_{3}$ & 2 & - & - & 1 & - & 2 \\
\hline & $\mathrm{OT}_{4}$ & - & 6 & 2 & - & 3 & - \\
\hline & $\mathrm{OT}_{5}$ & 6 & - & 3 & 3 & - & 4 \\
\hline & $\mathrm{OT}_{6}$ & 1 & 4 & - & 2 & - & - \\
\hline & TSR & 7 & - & 4 & - & 4 & 5 \\
\hline & TStR & - & 2 & 4 & - & - & - \\
\hline & TPR & 10 & 1 & - & 5 & 2 & - \\
\hline \multirow{6}{*}{ Other Units } & TC1 & - & - & 5 & 4 & - & 2 \\
\hline & TC2 & - & 5 & - & 2 & 3 & - \\
\hline & TReR & 15 & 3 & 8 & 8 & 3 & 3 \\
\hline & TIR & - & 4 & 5 & - & - & - \\
\hline & TRR & 8 & - & - & 6 & 6 & 2 \\
\hline & $\mathrm{Tt}$ & 10 & 8 & 6 & 5 & - & - \\
\hline \multirow[t]{2}{*}{ Total } & 224 & 63 & 36 & 44 & 40 & 21 & 20 \\
\hline & $100 \%$ & $(28.1 \%)$ & $(16.1 \%)$ & $(19.6 \%)$ & (17.9\%) & $(9.4 \%)$ & $(8.9 \%)$ \\
\hline
\end{tabular}

$\mathbf{T}_{1}$, Theatre 1, $\mathbf{T}_{2}$, Theatre 2, $\mathbf{T}_{3}$, Theatre $3, \mathbf{T}_{4}$, Theatre $4, \mathbf{T}_{5}$, Theatre $5, \mathbf{T}_{6}$, Theatre 6 , TSR, theatre seminar room, TSrR, theatre sterile room, TPR, theatre pharmacy room, $\mathbf{T} \mathbf{C}_{1}$, theatre corridor $1,\left(\mathbf{T C}_{2}\right)$, theatre corridor 2 , TReR, theatre reception room, TIR, theatre instrument room, TRR, theatre recovery room, and $\mathbf{T t}$, theatre toilets.

Table 3. Comparative sensitivity of isolated bacteria to different concentrations of UDUTH and pharmacy povidone iodine.

\begin{tabular}{lcccccccc}
\hline \multirow{3}{*}{ Bacterial Species } & \multicolumn{3}{c}{ Zones of inhibitions ( $\mathbf{m m}$ ) at different concentration of two sets of disinfectants } \\
\cline { 2 - 9 } & \multicolumn{3}{c}{ Povidone iodine from UDUTH } & \multicolumn{5}{c}{ Povidone iodine from pharmacy store } \\
\cline { 2 - 9 } & $\mathbf{2 \%}$ & $\mathbf{3 \%}$ & $\mathbf{4} \%$ & $\mathbf{5 \%}$ & $\mathbf{2 \%}$ & $\mathbf{3 \%}$ & $\mathbf{4} \%$ & $\mathbf{5 \%}$ \\
\hline Bacillus megaterium & 0.00 & 0.00 & 0.00 & 0.00 & 7.75 & 9.80 & 11.50 & 13.50 \\
S. epidermidis & 0.00 & 0.00 & 0.00 & 0.00 & 8.50 & 12.25 & 15.00 & 17.50 \\
S. aureus & 0.00 & 0.00 & 0.00 & 0.00 & 8.00 & 8.00 & 12.00 & 18.00 \\
B. subtilis & 0.00 & 0.00 & 0.00 & 0.00 & 8.30 & 9.16 & 9.83 & 11.00 \\
B. cereus & 0.00 & 0.00 & 0.00 & 0.00 & 8.35 & 8.40 & 9.00 & 10.00 \\
Streptococcus sp & 0.00 & 0.00 & 0.00 & 0.00 & 8.40 & 9.00 & 9,20 & 11.50 \\
\hline
\end{tabular}

concentration of $5 \%$ and $B$. megaterium has the least zone of inhibition of $7.75 \mathrm{~mm}$ at $2 \%$ of povidone.

The sensitivity of isolated bacterial species to different concentration of Izal solution was obtained (Table 4). The isolates were sensitive to all the concentration used, $B$. cereus was most sensitive with the highest zone of inhibition $17.30 \mathrm{~mm}$ at a concentration of $8 \%$ while $B$. megaterium had the least zone of inhibition $6.08 \mathrm{~mm}$ at $2 \%$ of Izal (Table 4).

The killing rate of Izal solution on $S$. aureus when exposed to $8 \%$ concentration was obtained. There was $\log$ of 4 reductions within the first $10 \mathrm{~min}$. Log of 1 reductions was also observed in the 20th min before the population suddenly dropped to zero in the 25th min (Figure 1).

The killing rates of Izal solution on $B$. megaterium when exposed to $8 \%$ concentration was shown in Figure 2. There was log of 4 reductions in the first $5 \mathrm{~min}$ and about $\log$ of 2 reductions in the following $20 \mathrm{~min}$ before the population dropped to zero in the 30th min (Figure 2).

Figure 3 showed the killing rates of Izal solution on $B$. cereus when exposed to $8 \%$ concentration. There was $\log$ of 4 reductions in the first $5 \mathrm{~min}$ and about log of 2 reductions in the following $20 \mathrm{~min}$ before population 
Table 4. Sensitivity of isolated bacterial species to different concentration of Izal.

\begin{tabular}{lcccc}
\hline \multirow{2}{*}{ Bacterial species } & \multicolumn{4}{c}{ Zones of Inhibition $(\mathbf{m m})$ from Different } \\
& $\mathbf{5}$ & $\mathbf{4 \%}$ & $\mathbf{6 \%}$ & $\mathbf{8 \%}$ \\
\cline { 2 - 5 } & $\mathbf{2 \%}$ & 7.00 & 8.87 & 10.08 \\
\hline Bacillus megaterium & 6.08 & 12.13 & 13.40 & 15.06 \\
Staphylococcus aureus & 9.33 & 11.00 & 13.00 & 17.30 \\
Bacillus cereus & 6.00 & 8.35 & 13.85 & 15.30 \\
Staphylococcus epidermidis & 7.50 & 11.00 & 12.00 & 16.00 \\
Bacillus subtilis & 9.00 & 10.00 & 15.00 & 17.00 \\
Streptococcus sp & 9.70 & & & \\
\hline
\end{tabular}

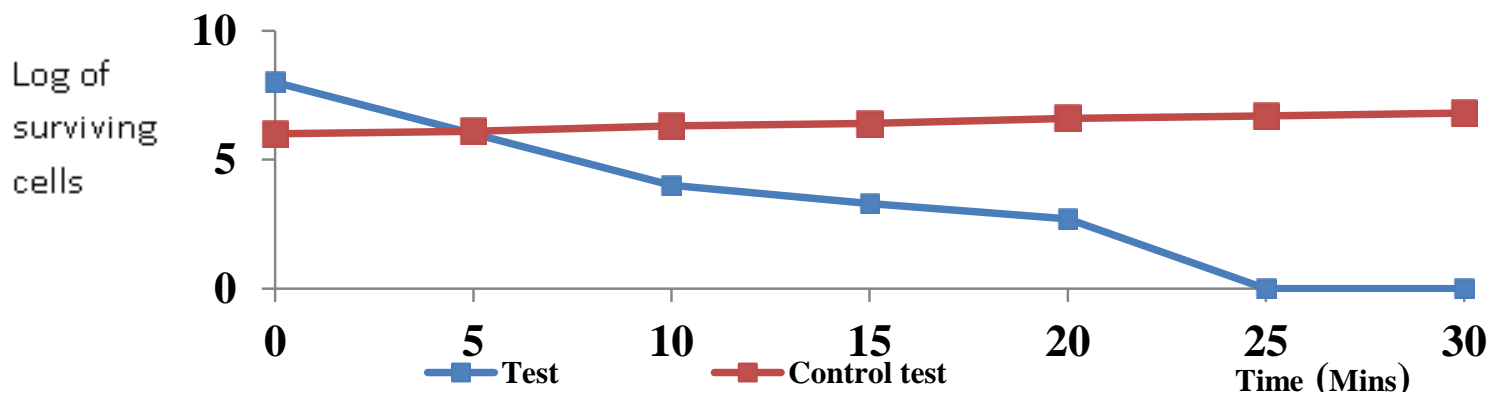

Figure 1. Killing rate of $S$. aureus when exposed to a dilution of $8 \%$ Izal for 30 minutes.

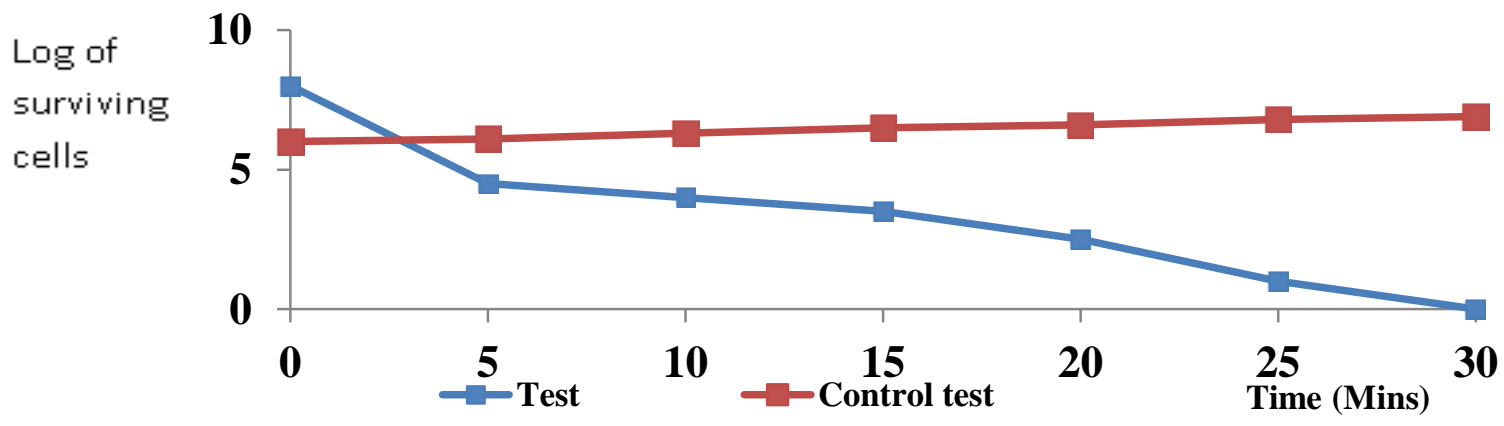

Figure 2. Killing rate of $B$. megaterium when exposed to a dilution of $8 \%$ Izal for 30 minutes.

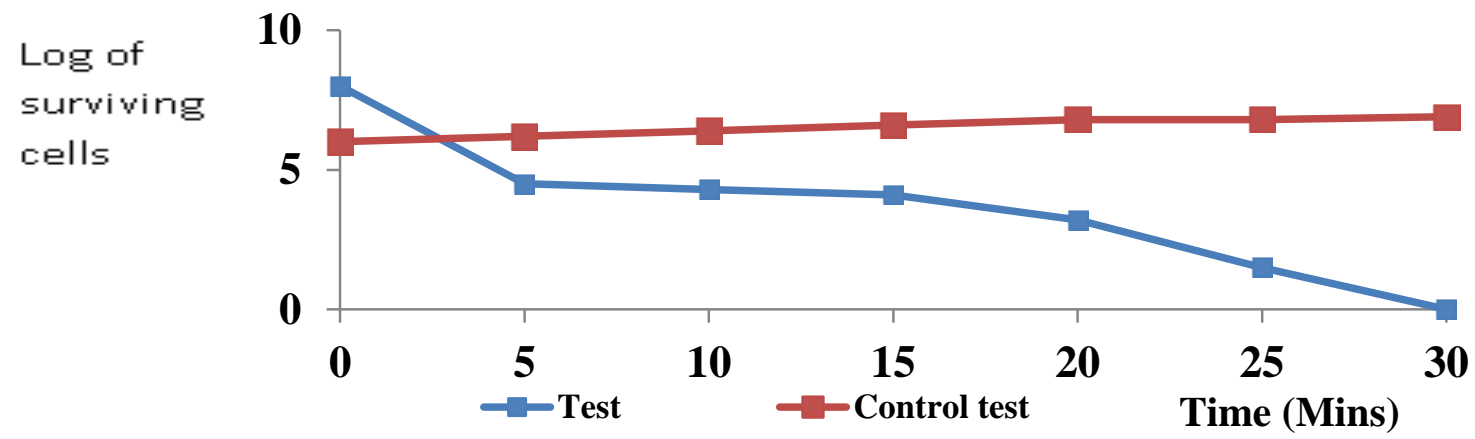

Figure 3. Killing rate of $B$. cereus when exposed to a dilution of $8 \%$ dilution Izal for 30 minutes. 
dropped to zero in the 30th min.

\section{Discussion}

Assessment of commonly used hospital disinfectants on bacteria isolated from the operating theatre was evaluated. The result of the isolated bacterial pathogens and its frequency of occurrence revealed that; bacterial load ranges from $20 \mathrm{cfu} / \mathrm{m}^{3}(8.9 \%)$ to $63 \mathrm{cfu} / \mathrm{m}^{3}(28.1 \%)$ as shown in Table 1. However, sources of microbial contamination in the operating theatre can be diverse, which include frequent movement of surgical and medical team, movement within the operating theatre, high presence of human population, especially the theatres staff and medical students, movement within these units might be responsible for bacterial contamination through theatre gown, foot wares, gloves and hands, drainage of the wounds, transportation of patients and collection bags. All these factors play a role in the bacterial load found in this research work, thereby contaminating the operating theatre and subsequently cause post-operative infection (Emerson, 2008 and Suzuki, et al., 2004).

The clinical implication of bacterial contamination in the operating theatre had enormous effect of infection on both the patients and the caring medical team. B. cereus and $S$. epidermidis are the most frequently isolated species and are mostly responsible for Nosocomial infection, these organisms are responsible for $50-70 \%$ of catheter-related infection among hospitalized patients and this has a great clinical impact on the patient. $B$. cereus can produce biofilms (Auger et al., 2009), which play a major role in attachment to catheters thereby prolonging healing process and leading to injurious infection. This study has further confirmed that the antimicrobial activities of two commonly in house used disinfectants at UDUTH, Sokoto, Nigeria, against clinical isolates are concentration-dependent; this is in agreement with the work done by Awodele et al., (2007).

The in-house used-concentration of $8 \%$ of the disinfectants used in UDUTH, showed good susceptibility only by Izal with diameters of zones of inhibition ranging between $10.08 \mathrm{~mm}$ and $17.30 \mathrm{~mm}$. But the results of susceptibility to povidone iodine collected from the operating theatres, tested on all clinical isolates showed that, povidone iodine formulated at $5 \%$ was not effective, this further confirms the work of Anderson and Sindelar (1999). Lack of sensitivity of the isolate to the disinfectant could be attributed to three main factors; Degradation of the disinfectant during storage, Storage temperature of the disinfectant, and Faking of the disinfectant by the producer.

According to Anderson and Slindelar (1999), povidone iodine is not always effective at killing common clinical isolates when stored for a prolonged period of time. It can also be contaminated by some bacteria known to have the ability to degrade chemical compounds. Pseudomonas aeruginosa have been reported to have this ability (Anderson and Slindelar, 1999). Storage temperature is another critical factor that could accelerate degradation of chemical disinfectant. At temperature above $40^{\circ} \mathrm{C}$, povidone iodine loses its potency. This result corroborates with the work of Nelson and Morri (2002).

According to Nelson and Morri (2002), rise in temperature above $37^{\circ} \mathrm{C}$ causes povidone iodine to degrade and weakens its germicidal activity. And most times, temperature in Sokoto State is above $40^{\circ} \mathrm{C}$, this would have affected the potency of the disinfectant adversely. Faking of the disinfectant is another important factor that can lead to the failure of the disinfectant. Sometime the percentage potency of the disinfectants is far below the claimed standard by the manufacturers (Cardoso et al., 1999). The end users rely on the information provided by the manufacturers to make dilution of the product thereby over diluting the products which renders it ineffective.

The result of povidone iodine purchased from a pharmacy store in town showed that the povidone iodine is effective at the formulated concentration of $5 \%$ against all isolated bacteria. Similar work by Berkelman et al. (1992) observed that povidone-iodine diluted to concentrations of $2 \%$ to $5 \%$ was more effective in killing common wound contaminants than that of $10 \%$ stock solution. This implied that the failure observed in the result of povidone iodine collected from the operating theatre may be as a result of one or combination of the factors mentioned above.

\section{CONCLUSION}

In conclusion, only izal used at UDUTH, at in house concentration of $8 \%$ is effective against all clinical isolates tested. The killing rate on resistant isolates shows that 25 to $30 \mathrm{~min}$ of exposure to the disinfectants is required to kill all viable cells of the isolates. However, it can be concluded that disinfection remain one of the most effective ways of reducing nosocomial pathogens in the hospital environment as demonstrated in the results of this research work. But from time to time, potency of the disinfectant in use in the hospital must be evaluated in order to keep pace with degradation of the disinfectant which normally occurs with time.

\section{CONFLICT OF INTEREST}

The authors declare that they have no conflict of interest.

\section{REFERENCES}

Allerberger, F., Ayliffe, G., Bassetti, M., Braveny, I, Bucher, A, \& Damani, N. (2002). Routine surface disinfection in health care facilities: should we do it? Am. Journal Infection Control, 30, 318-319. 
Anderson, R. L., \& Sindelar, W. F. (1999). Intrinsic microbial contamination with resident bacteria. Infection Control Hospital Epidemiology, 10, 443-446.

Auger, S. N., Ramarao, C., Faille, A., Fouet, S., Aymerich, S., \& Gohar, M. (2009). Biofilm formation and cell surface properties among pathogenic and nonpathogenic strains of the Bacillus cereus group. Applied Environmental Microbiology, 8: 155-159.

Awodele, O., Emeka, P. M., Agbamuche, H. C., Akintonwa, A. (2007). The antimicrobial activities of some commonly used disinfectants on Bacillus subtilis, Pseudomonas aeruginosa and Candida albicans. Africa Journal Biotechnology, 8, 887990.

Barrow, N., \& Felthem, A. (1993). Cowan and steel manual for identification of medical important bacteria. Cambridge university press, 2, 209-220.

Berkelman, R. L., Holland, B. U., \& Anderson, R. L. (1992). Increased bactericidal activity of dilute preparations of povidone-iodine solutions. Journal Clinical Microbiology, 15, 635-639

Cardoso, C. L., Pereira, H. H., Zequim, J. C., Guilhermetti, M. (1999). Effectiveness of hand-cleansing agents for removing Acinetobacter baumannii strain from contaminated hands. Am. Journal Infection Control, 27, 327-331.

Emerson, M. A. (2008). A microbiologist's view of factor contributing to infection. A New horizon (Baltmore, Md), 6, S3-S10

Frindkin, G., Lidwell, O., Jarvis, H. (1996). Influence operating room surfaces contamination on surgical wounds. Journal Environmental Health, 18, 484-488.

Higgins, C. S., Murtough, S. M., Hiom, S.J., Payne, D. J., Russel, A. D., \& Walsh, T. R. (2001). Resistance to antibiotics and biocides among non-fermenting Gram- negative bacteria. Clinical Microbiology Infection Disease, 7, 308-315.

Kelsey, J. C., \& Maurer, I. M. (2001). An improved KelseySykes test for disinfectants. Pharmaceutical Microbiology Journal, 6, 607-609.

Kim, Y. M., Farrah, S., \& Baney, R. H. (2007). Structureantimicrobial activity relationship for silanols, a new class of disinfectants, compared with alcohols and phenols. International Journal Antimicrobial Agent, 29, 217-222.

MacBain, A. J., Ledder, R. G., Moore, L. E., Catrenich, C. A., Gilbert, P. (2004). Effects of quartenary-ammonium-based formulation on bacterial community dynamics and antimicrobial susceptibility. Applied Environmental Microbiology Journal, 70, 3449-3456.

MacCullouch, D., \& Cameron, G. L., (2002). A bacteriological survey of an operating theatre environment. Nigerian Medical Journal, 36, 327-303.
McDonnel, G., \& Russel, D. (2001). Antiseptics and disinfectants: activity, action, and resistance. Clinical Microbiology Review, 12, 147-149.

NCCLS. (1999). Document Performance Standards for Antimicrobial Disk Susceptibility Test $4^{\text {th }}$ Edition, 10.

Nelson, P. S., \& Morri, G. H. (2002). Bacteria in laundered fabrics. Am Journal Public Health, 3, 2175-2180

Onalopo, H. A. (1997). Performance Standard for antimicrobial susceptibility test, S18. Clinical and laboratory standard institutes.

Russel, A. D., \& Russel, N. J. (2005). Biocides: activity, action and resistance. Society General Microbiology, 53: 327-365.

Rutala, W. A., \& Weber, D. J. (2001). Surface disinfection: should we do it? Journal Hospital Infection, 48, 864-868.

Rutala, W. A., Siegel, M. M., Sambbi, E. A., Weber, D. J. (2007). Susceptibility of antibiotic-susceptible and antibioticresistant hospital bacteria to disinfectants. Infection Control Hospital Epidemiology,18, 417-421.

Saurina, G., Landman, D., Duale, J. M. (1997). Activity of disinfectants against vancomycin-resistant Enterococcus faecium. Infection Control Hospital Epidemiology,18, 345347.

Suzuki, A., Namba, Y., Matsuura, M., Horisawa, A. (2004). Bacterial contamination of floors and other surfaces in operating rooms; a five years suvey. Journal Hygiene Combinations, 33, 559-566

Taiwo, S. S., Okesina, A. B., Onile, B. A. (2002). "Invitro Antimicrobial Susceptibility Pattern of Bacterial Isolates from Wound Infections in University of Ilorin Teaching Hospital," African Journal of Clinical and Experimental Microbiology, 3, 6-10.

Zavascki, A. P., Cruz, R. P., Goldani, L. Z. (2005). Risk factors for imipenem resistant Pseudomonas aeruginosa; a comparative analysis of two case-control studies in hospitalized patients. Journal Hospital Infection. 59, 96-101.

Zerr, D. M., Garrision, M. M., Allpress, A. L., Heath, J. D. A., Christakin, D. A. (2005). Infection Control policies and hospital associated infection among surgical patient; Variability or association in a multicentre pediatrics setting, 387-392. 